\title{
PELATIHAN KEWIRAUSAHAAN : STRATEGI MENINGKATKAN PENJUALAN ONLINE DI MASA COVID- 19 MELALUI SOSIAL MEDIA BAGI UMKM DI KABUPATEN LAHAT
}

\author{
Angga Wibowo Gultom ${ }^{1^{*}}$, Dyah Ayu Putriani ${ }^{2 *}$ \\ ${ }^{1,2}$ Universitas Baturaja, Sumatera-Selatan. \\ ${ }^{3}$ Program Studi Manajemen, Fakultas Ekonomi dan Bisnis \\ mr.angga.gultom@gmail.com ${ }^{1}$,dyahayujuvedona@gmail.com ${ }^{1}$
}

\begin{abstract}
Abstrak
Masa pandemi covid-19 membuat pemerintah melakukan banyak pembatasan interaksi dan kegiatan sosial masyarakat yang berakibat menurunnya transaksi penjualan secara offline bagi UMKM. Sangat penting bagi UMKM untuk segera beralih dan menyediakan akses pelayanan penjualan melalui sistem online melalui sosial media agar dapat kembali menjangkau konsumen dan meningkatkan penjualan. UMKM di wilayah lahat termasuk UMKM yang sangat membutuhkan pelatihan penjualan online melalui sosial media, mengingat Kabupaten Lahat termasuk dalam kategori merah penyebaran covid-19 yang berarti pembatasan interaksi sosial secara offline dilakukan. Pelatihan kewirausahaan ini dilakukan dengan metode presentasi, tatap muka, diskusi, serta praktek pembuatan dan optimasi sosial media. Hasil dari pelatihan ini seluruh pelaku UMKM dikabupaten Lahat memiliki akun dan mampu mengoptimasi sosial media yang mereka miliki untuk melakukan transaksi online dan meningkatkan penjualan di masa pandemi covid-19
\end{abstract}

Kata Kunci : Kewirausahaan, Covid-19, penjualan, online, UMKM

\section{Abstract}

During the Covid-19 pandemic, the government made many restrictions on social interactions and activities, which resulted in a decrease in offline sales transactions for MSMEs. It is very important for MSMEs to immediately switch and provide access to online sales services system through social media so that they can reach consumers again and increasing sales. MSMEs in the Lahat area include MSMEs that really need online sales training through social media, considering that Lahat Regency is included in the red category of the spread of covid-19 which means that restrictions on offline social interaction. This entrepreneurship training is carried out using the methods of presentation, face to face, discussion, and the practice of creating and optimizing social media. The results of this training, all MSME in Lahat Regency have accounts and are able to optimize their social media to make online transactions and increase sales during the Covid-19 pandemic.

Keywords: Entrepreneurship, Covid-19, sales, online, MSMEs

\section{PENDAHULUAN}

Covid-19 adalah kepanjangan dari sebuah pandemi coronavirus disease 2019. Sebuah penyakit menular dan mematikan yang disebabkan oleh SARSCoV-2, salah satu jenis dari Corona Virus. Virus ini pertama kali muncul ke permukaan pada 1 Desember 2019 di China, tepatnya di daerah Wuhan Provinsi Hubei, China. Sebagian ilmuwan mengklaim bahwa pusat rantai penyebaran virus ini berada di sebuah pasar hewan ternak dan ikan laut di Huanan Wuhan, China. Namun pihak berwenang China menolak klaim tersebut karena pasien pertama yang terdiagnosis Covid-19 bukanlah orang yang tinggal di daerah pasar tersebut. Dampak pandemi virus corona (Covid-19) sangat terasa di dunia bisnis dan ekonomi. Dalam waktu yang cukup singkat, pola pemasaran pun berubah terlebih ketika diberlakukan social distancing dan Pembatasan Sosial Berskala Besar (PSBB). Pemasar harus putar otak 
Seminar Nasional Penelitian dan Pengabdian kepada Masyarakat Universitas Sang Bumi Ruwa Jurai Tahun 2020

untuk bisa memasarkan produk atau jasa mereka ke konsumen, sebagai strategi brand bertahan di tengah pandemi virus corona. Para pelaku bisnis mengoptimalkan pemasaran online dan digital branding sebagai sarana komunikasi dengan target konsumennya.

Pandemi COVID-19 memiliki dampak besar terhadap segala aspek dan sektor di kehidupan masyarakat terutama pada sektor ekonomi. Menteri Keuangan Sri Mulyani mengatakan ada 3 dampak besar ekonomi pada pandemi COVID-19. Pertama, berdampak pada konsumsi rumah tangga atau daya beli masyarakat yang jatuh. Kedua, investasi ikut melemah ditengah ketidakpastian pandemi COVID-19. Ketiga, pelemahan ekonomi seluruh dunia yang membuat ekspor Indonesia terhenti dikarenakan menurunnya kegiatan masyarakat di luar rumah, maka secara otomatis juga menimbulkan penurunan jumlah pembeli pada suatu usaha. Sehingga pendapatan yang diperoleh menjadi berkurang. Dampak tersebut tidak hanya dirasakan oleh industri besar, pandemi virus Corona juga memberikan dampak terhadap pelaku Usaha Mikro, Kecil, dan Menengah (UMKM) di Indonesia.

Tantangan perekonomian sekarang ini memang sangatlah berat karena masyarakat dalam kondisi waspada dan sangat berhati-hati dengan membatasi bepergian keluar rumah. Tentunya hal ini berdampak pada transaksi jual beli di pasaran yang menurun. Tak hanya itu, sebagian pasar yang dipaksa tutup guna memutus rantai penyebaran Covid-19 mengakibatkan para pelaku usah kehilangan lapaknya dan tak ada lagi istilahnya tempat untuk mempromosikan produk hasil usahanya. Berbagai elemen yang terkena dampaknya yaitu perusahaan besar, restoran, pusat perbelanjaan, angkutan umum, dan juga UMKM.

Beranjak dari hal demikian maka perlu motivasi/dorongan dari stakeholders atau entitas entitas terkait yang berhubungan langsung dengan sektor swasta agar memfokuskan untuk membantu UMKM melalui peningkatan sumber daya manusia (SDM) seperti pelatihan, promosi dan pendampingan agar UMKM tersebut maju dan berkembang. Hal ini diungkapkan oleh Suyatno (2000:146) bahwa untuk meningkatkan daya saing UMKM diperlukan langkah bersama untuk mengangkat kemampuan teknologi dan daya inovasinnya. Dalam hal ini inovasi berarti sesuatu yang baru bagi si penerima yaitu komunitas usaha mikro kecil dan memengah, (UMKM) yang bersangkutan. Kemajuan ekonomi terkait dengan tingkat perkembangan yang berarti melalui tahap penguasaan teknologi.

Usaha mikro, kecil, dan menengah atau yang biasa disebut UMKM merupakan aktivitas atau kegiatan ekonomi yang membantu dan berperan penting dalam perekonomian Indonesia dengan jumlah tenaga kerja dalam batas tertentu. Menurut (HELMALIA \& AFRINAWATI, 2018), UMKM merupakan alternatif yang mampu mengurangi beban berat yang dihadapi oleh perekonomian nasional. Usaha mikro, kecil, dan menengah mampu menjadi tulang punggung perekonomian nasional karena merupakan usaha yang paling strategis dan menyangkut hajat hidup orang banyak (Wicaksono \& Nuvriasari, 2012).

Kinerja nyata yang dihadapi oleh sebagian besar usaha terutama pelaku UMKM yang paling menonjol adalah minimnya sumber daya manusia, kreativitas dan inovasi, tidak membaca peluang usaha, dan meniru usaha yang sudah sukses. Situasi dan kondisi seperti ini yang membuat usaha mikro kecil produktivitasnya masih minim bila bersaing dengan usahausaha menengah dan besar.

Di zaman sekarang dengan perkembangan teknologi dan komunikasi yang semakin canggih, pemilihan penggunaan pemasaran melalui media sosial menjadi pilihan utama yang dilakukan oleh pelaku usaha, sekarang ini penggunaan media sosial telah menjadi pilar utama 
dalam penyampaian informasi. Salah satu kelebihan media sosial adalah memiliki banyak potensi untuk kemajuan suatu usaha. Media sosial dapat digunakan untuk melakukan komunikasi dalam bisnis, membantu pemasaran produk dan jasa, berkomunikasi dengan pelanggan dan pemasok, melengkapi merk, mengurangi biaya dan untuk penjualan online (Achmad \& Setiyanti, 2015).

Dalam dunia bisnis saat ini, generasi milenial sudah sangat banyak yang memulai bisnis online menggunakan media pemasaran media sosial. Kunci sukses menjalankan komunikasi bisnis adalah media yang seperti apa yang dapat memudahkan untuk mempromosikan produk atau jasa yang akan dijual. Media sosial menjadi referensi utama generasi milenial yang membutuhkan modal kecil untuk mengiklankan barang dan jasanya. Media sosial merupakan media secara online yang bisa digunakan siapapun, kapanpun dan dimanapun konsumen berada. Selama fasilitas internet mendukung maka media sosial bisa dipergunakan secara maksimal. Sebagai media yang bisa diakses oleh banyak orang, media sosial dapat dimanfaatkan untuk membuat sebuah strategi promosi bisnis tanpa dipungut biaya untuk beriklan. Selain itu, kreativitas sumber daya manusianya arus juga pandai mengemas produk barang dan jasa saat dipromosikan di media sosial.

Saat ini pemanfaatan internet juga sangat berkembang pada berbagai aspek kehidupan, terutama social media dimana social media merupakan sebuah media komunikasi tanpa harus bertatap muka untuk bersosialisasi dan interaksi yang dapat dikunjungi oleh setiap orang yang memiliki gadget. Saat ini pula social media menjadi solusi terbaik untuk membantu perekonomian UMKM tetap lancar. Sehingga pelaku usaha harus tetap memanfaatkan media social ataupun internet untuk menjaga kelancaran perekonomian UMKM seperti memanfaatkan E-commerce yang saat ini sedang digemari oleh para produsen dimana dapat mempermudah produsen dalam menawarkan produknya dan melakukan transaksi dan juga mempermudah konsumen untuk membeli produknya tanpa harus keluar rumah. Jadi, promosi melalui media online lebih mudah menjangkau konsumen dalam hal memperkenalkan atau menjual produknya.

Media sosial yang saat ini menjadi tren anak-anak muda mengekspresikan diri menjadi peluang besar sebagai media iklan maupun promosi bisnis. Media sosial seperti Facebook, Instagram, Twitter, WhatsApp, dan lain sebagainya sekarang banyak dimanfaatkan untuk media bisnis, baik dari produk produk yang sudah ternama hingga produk buatan sendiri. Dengan internet para pelaku usaha dapat memberikan efisiensi anggaran pemasaran, internet memiliki jangkauan yang luas, akses mudah dan biaya murah. Hal ini terbukti dengan banyaknya usaha yang mencoba menawarkan berbagai macam produk menggunakan media sosial (Tutiasri et al., 2020). Media sosial memang sangat diminati UMKM untuk mengembangan bisnisnya. Media sosial mempunyai pengaruh yang sangat besar, masyarakat lebih cepat menerima informasi lewat internet. Dengan akses yang mudah dan cepat hal ini dimanfaatkan oleh para pengusaha kecil UMKM untuk lebih berani mempromosikan produk produknya karena jaringan internet sangat luas dan tidak ada batasan waktu dan wilayah hingga menjadikan media pemasaran yang efektif (Purbohastuti, 2017).

Menurut (Gunelius, 2013) perubah kesuksesan social media marketing adalah content creator (konten dibuat menarik), content sharing (konten dibagikan kepada komunitas sosial), connecting (jaringan luas membangun hubungan untuk menghasilkan banyak bisnis) dan community building (membangun komunitas di Internet). Sehingga, sangatlah penting dilakukan pelatihan pemasaran secara online dengan memanfaatkan media sosial pada Usaha Kecil dan Menengah (UKM) di Indonesia guna meningkatkan hasil penjualan mitra. 
Seminar Nasional Penelitian dan Pengabdian kepada Masyarakat

Universitas Sang Bumi Ruwa Jurai Tahun 2020

\section{METODE PENELITIAN}

Kegiatan ini dilaksanakan pada hari Kamis sampai dengan Sabtu tanggal 17-19 September 2020. Tahap Implementasi/ pelaksanaan kegiatan ini adalah terdiri dari beberapa tahap yaitu adalah sesi ceramah, sesi tanya jawab serta sesi diskusi. Pemateri membahas mengenai strategi bagaimana penjualan online dan membahasa mengenai perencanaan bisnis, legalitas, sosial media dan market place. Peserta menyampaikan permasalahan yang di alami padaa masa yang sangat sulit saat pandemi ini, sehingga sharing permasalahan yang terjadi dengan sistem diskusi.

\section{HASIL PEMBAHASAN}

Hasil yang telah dicapai berdasarkan pelaksanaan kegiatan Pengabdian Kepada Masyarakat (PKM) yang telah dilaksanakan dapat identifikasi sebagai berikut:

1. Mayoritas UMKM peserta pelatihan di lahat belum tahu sama sekali tentang rencana bisnis (57\%), terdapat juga UMKM yang sudah pernah mendengar namun belum mengetahui secara lengkap (40\%) dan hanya ada 1 UMKM yang sudah tahu dan telah membuatnya secara sederhana (3\%) dan belum ada satupun UMKM yang telah membuat dan mengaplikasikan rencana bisnisnya $(0 \%)$. Setelah mengikuti kegiatan, seluruh UMKM peserta pelatihan telah mengetahui dan telah membuat rencana bisnis secara sederhana (100\%), nantinya rencana bisnis ini akan mereka gunakan dalam mengaplikasikan bisnisnya.

2. Mayoritas UMKM peserta pelatihan di lahat telah memahami bahwa membuat perencanaan dalam produksi,pemasaran dan pembiayaan dalam bisnis adalah hal yang penting (77\%), terdapat juga UMKM yang sudah paham ke level sangat penting (16\%) namun terdapat juga UMKM yang menganggapnya sebagai hal yang biasa saja (7\%) dan belum ada satupun UMKM yang menganggap ini tidak penting (0\%). Mayoritas UMKM peserta pelatihan telah memiliki kesadaran bahwa Perencanaan dalam produksi, pemasaran dan pembiayaan dalam bisnis adalah hal yang sangat penting $(90 \%)$, dan sisanya (10\%) sudah memiliki kesadaran di level penting.

3. UMKM peserta pelatihan di lahat tentang izin legalitas sangat beragam, ada yang sudah ada (23\%), namun mayoritas UMKM menjawab tidak ada (47\%) dan ada juga yang menjawab tidak tahu atau belum mengerti (30\%). Setelah mengikuti kegiatan, seluruh UMKM peserta pelatihan telah memiliki legalitas usaha (100\%), selanjutnya legalitas usaha ini akan disimpan dan direkomendasikan untuk diperbaharui apabila sudah mendekati masa izin yang akan habis.

4. Mayoritas UMKM peserta pelatihan di lahat belum memiliki social media yang lengkap, namun sudah dimanfaatkan untuk jualan online (63\%), sedangkan yang sudah lengkap (13\%) yang belum lengkap dan belum dimanfaatkanuntuk jualan online (17\%) dan yang belum memiliki social media (7\%). Setelah mengikuti kegiatan, sebagian besar UMKM peserta pelatihan telah memiliki akun sosial media yang lengkap dan dimanfaatkan untuk jualan online $(77 \%)$, dan ada yang belum lengkap namun sudah dimanfaatkan untuk jualan online $(23 \%)$.

5. Mayoritas UMKM peserta pelatihan di lahat belum memiliki produk yang mereka jualdimarketplace (90\%), namun sudah ada UMKM yang sudah melakukan penjualan produk (3\%) dan ada UMKM yang tidak tahu dan belum mengerti tentang menjual 
produk di marketplace (7\%). Setelah mengikuti kegiatan, Mayoritas UMKM Lahat peserta pelatihan telah memiliki akun dan siap melakukan penjualan secara online melalui marketplace (93\%), sedangkan sisanya, masih terdapat UMKM yang belum memiliki akun marketplace untuk jualan online $(7 \%)$.

6. Mayoritas UMKM peserta pelatihan di lahat tidak tahu dan belum mengerti tentang pentingnya landing page atau website untuk bisnis (63\%), namun ada UMKM yang sudah merasa penting (23\%) dan hanya ada UMKM yang menganggap tidak penting (14\%) sedangkan untuk UMKM yang merasa sangat penting ternyata tidak ada $(0 \%)$. Mayoritas UMKM Lahat peserta pelatihan telah menyadari bahwa peran lending page dan website untuk bisnis sangat penting(93\%), sedangkan sisanya, UMKM menjawab penting $(7 \%)$.

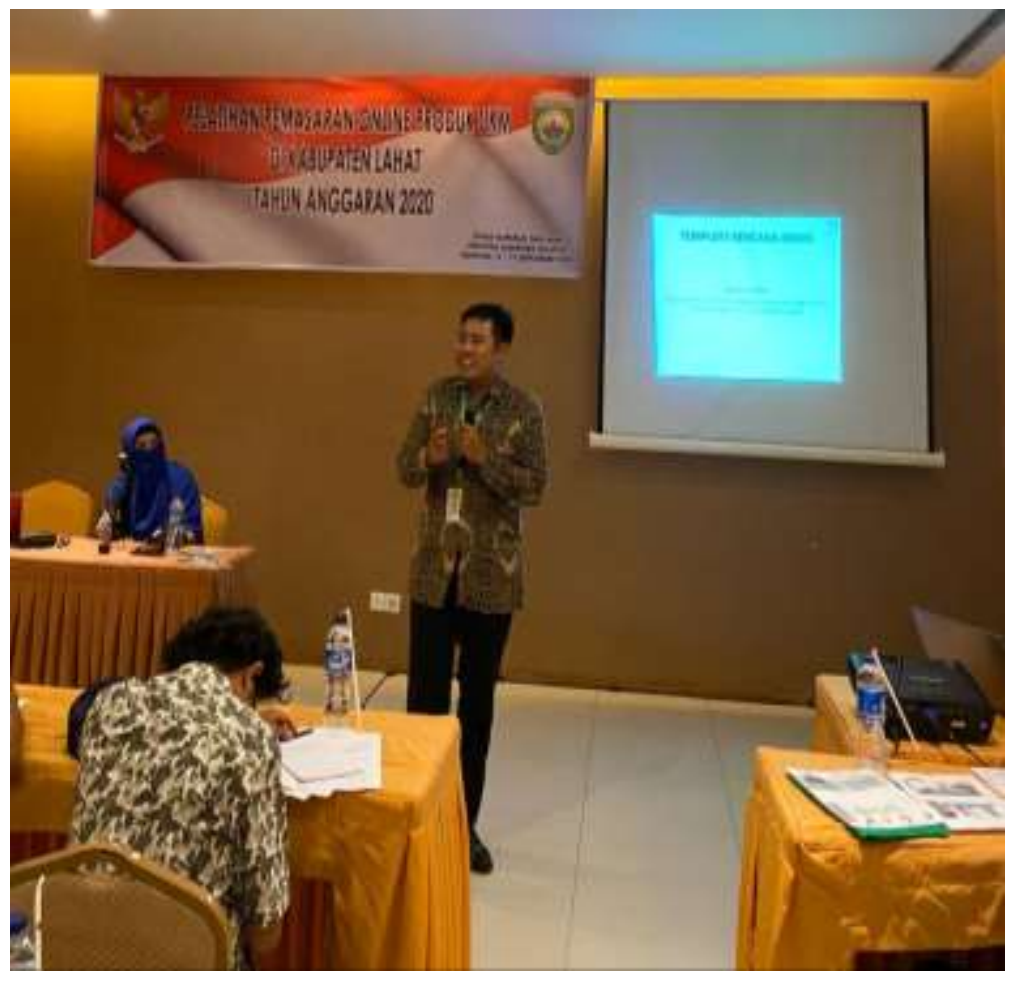

Gambar 1. Pemberian Materi Kepada Peserta UMKM 


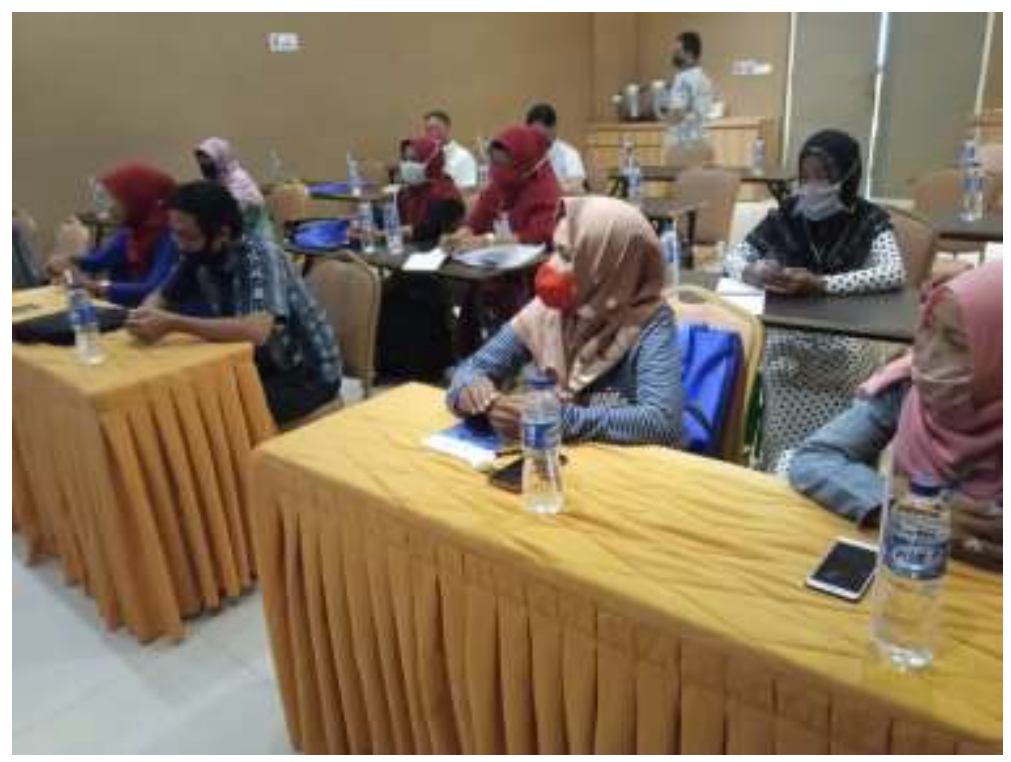

Gambar 2. Kegiatan Pengabdian Kepada Masyarakat

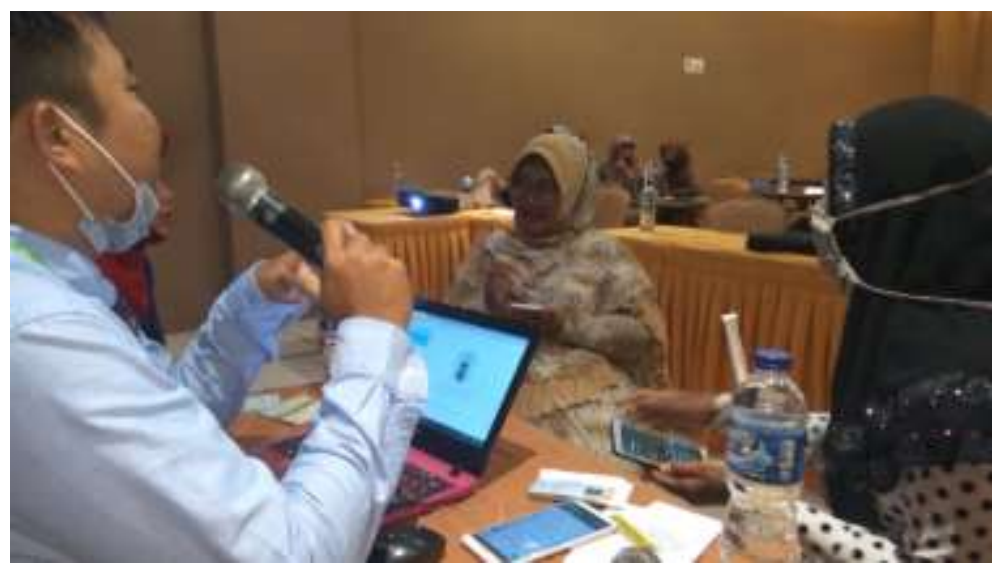

Gambar 3. Diskusi dan Konsultasi

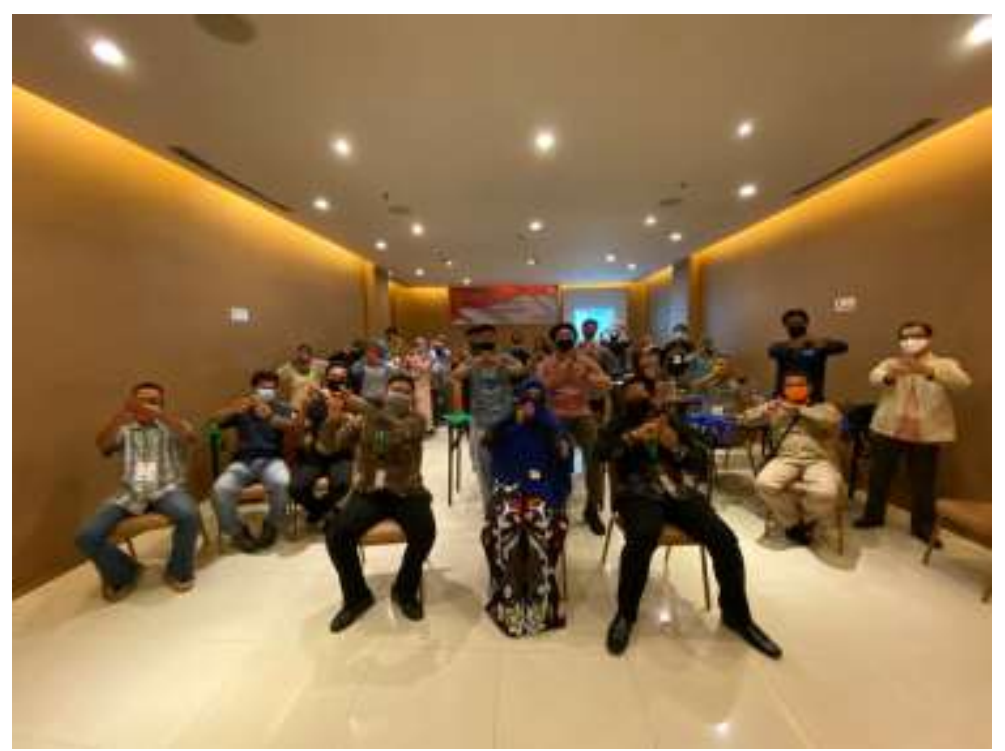


Seminar Nasional Penelitian dan Pengabdian kepada Masyarakat Universitas Sang Bumi Ruwa Jurai Tahun 2020

\section{Gambar 4. Foto Bersama Pemateri dan Peserta PkM}

\section{KESIMPULAN}

Kegiatan pelatihan digital marketing dengan sub tema membuat perencanaan bisnis telah berhasil memotivasi para UMKM peserta pelatihan untuk mengetahui dan membuat rencana bisnis secara sederhana, selanjutnya direkomendasikan kepada seluruh UMKM untuk mengaplikasikannya dalam bisnis agar bisnisnya bisa tumbuh sesuai dengan perencanaan yang telah dibuat dan kegiatan pelatihan telah berhasil memotivasi dan membuat para UMKM peserta pelatihan memiliki kesadaran akan pentingnya membuat Perencanaan dalam produksi, pemasaran dan pembiayaan dalam bisnis. Kegiatan telah berhasil memberikan pemahaman kepada para UMKM peserta pelatihan akan pentingnya legalitas izin usaha bagi UMKM, sehingga seluruh UMKM peserta pelatihan termotivasi untuk membuat izin online melalui sistem online single submission (OSS) dengan dibantu oleh tim fasilitator dari Klinik UMKM Bersama Sumatera-Selatan. Di akhir pelatihan seluruh peserta UMKM berhasil memiliki izin online dari sistem OSS.

Kegiatan ini telah berhasil memotivasi para UMKM peserta pelatihan untuk membuat dan melengkapi akun sosial media untuk bisnis mereka dan digunakan untuk berjualan online, tantangan dibidang ini adalah teknis pembuatan dan optimasi sosmed, namun tim KUBSS berhasil mendampingi seluruh UMKM untuk memiliki sosmed dan memanfaatkannya untuk jualan dan telah berhasil membuat mayoritasUMKM Lahat peserta pelatihan untuk membuat dan memiliki akun di marketplace, sehingga siap melakukan penjualan online, namun demikian masih terdapat UMKM yang belum siap melakukan penjualan online di marketplace karna lebih disebabkan kendalateknis seperti kesiapan konten, deskripsi termasuk kesiapan untuk produksi produk secara massal dan juga telah berhasil membuat mayoritas UMKM peserta pelatihan lebih menyadari akan sangat pentingnya penjualan produk melalui landing page dan website, pentingnya kesadaran ini diharapkan akan memicu paraUMKM untuklebih terbuka dan mula imengakses dunia digital untuk memasarkan produk mereka secara online.

\section{UCAPAN TERIMA KASIH}

Terima kasih kepada pihak Dinas Koperasi dan UMKM Provinsi Sumatera Selatan dan Para Peserta UMKM Kabupaten Lahat yang telah memberikan kesempatan dan meluangkan waktu dalam pelaksanaan kegiatan Pelatihan Kewirausahaan mengenai Strategi Meningkatkan Penjualan Online di Masa Covid-19 melalui sosial media bagi UMKM di Kabupaten Lahat.

\section{DAFTAR PUSTAKA}

Achmad, Z. A., \& Setiyanti, O. W. (2015). The Effectiveness of Use of Soundcloud Application for Promoting Pop Punk Songs and Music. Bali International Seminar on Science and Technology.

Gunelius, S. (2013). Can Small Businesses Really Afford Celebrity Endorsements? Forbes.

Helmalia, h., \& afrinawati, a. (2018). Pengaruh e-commerce terhadap peningkatan pendapatan usaha mikro kecil dan menengah di kota padang. Jebi (jurnal ekonomi dan bisnis islam). Https://doi.org/10.15548/jebi.v3i2.182

Purbohastuti, a. W. (2017). Efektivitas media sosial sebagai media promosi. Tirtayasa Ekonomika. https://doi.org/10.35448/jte.v12i2.4456 
Seminar Nasional Penelitian dan Pengabdian kepada Masyarakat Universitas Sang Bumi Ruwa Jurai Tahun 2020

Tutiasri, R. P., Febriyanti, S. N., Huzain, A. F., \& Nugroho, A. S. (2020). Creative Marketing Strategies of Sembung Batik. https://doi.org/10.2991/assehr.k.200325.030

Wicaksono, G., \& Nuvriasari, A. (2012). Meningkatkan Kinerja UMKM Industri Kreatif Melalui Pengembangan Kewirausahaan dan Orientasi Pasar: Kajian pada Peran Serta Wirausaha Wanita di Kecamatan Moyudan, Kabupaten Sleman, Propinsi DIY. Jurnal Sosio Humaniora. 